Article

\title{
Natural Seepage of Methane and Light Alkanes at Three Locations in Southern California
}

\author{
Brynne M. Weed, Gisselle D. Brambila and Lambert A. Doezema * (DC
}

Department of Chemistry and Biochemistry, Loyola Marymount University, Los Angeles, CA 90045, USA; bweed1@lion.lmu.edu (B.M.W.); gbrambil@lion.lmu.edu (G.D.B.)

* Correspondence: ldoezema@lmu.edu

Received: 29 May 2020; Accepted: 9 September 2020; Published: 12 September 2020

\begin{abstract}
Methane and light $\left(C_{2}-C_{5}\right)$ alkane fluxes were measured from three geologic seepage sites in Southern California during May and June of 2019. Samples were collected from visible macroseeps in Carpinteria, McKittrick, and Ojai using an aluminum flux chamber with attached stainless-steel canisters and were analyzed for $C_{1}$ to $C_{5}$ alkanes via gas chromatography. Carpinteria fluxes were characterized by a lower percentage of volatile organic compounds relative to methane but greatly enhanced ( 20:1) ratios of $i$-butane to $n$-butane. McKittrick and Ojai exhibited less methane-rich emissions and $i$-butane to $n$-butane ratios of less than 2:1. The differences between gas ratios observed at the surface and those previously reported from underground gas deposits at Ojai suggest that gases undergo alterations to their molecular composition between deposit and surface. The ratios of emitted gases in this study show that not only does geologic seepage have a much different volatile organic compound profile than oil and natural gas extraction and pipeline natural gas, but also that individual geologic seepage locations exhibit large variability.
\end{abstract}

Keywords: geologic seepage; macroseepage; methane; light alkanes; oil and natural gas

\section{Introduction}

Geologic seepage from underground oil and natural gas deposits is a source of methane and volatile organic compounds (VOCs) to the atmosphere that is sometimes overlooked. This seepage can occur in marine and terrestrial environments. Terrestrial seepage can occur in three ways, via microseepage, macroseepage, or miniseepage. Microseepage occurs when seepage from underground oil and natural gas deposits exit the earth's surface with no accompanying visible signs. Macroseepage (Figure 1) is observed when there is a visible escape of gases from underground deposits. Macroseepage is caused by pressure and buoyancy bulk fluid flow in locations where significant cross-stratal migration occurs [1]. It is capable of moving large amounts of liquids and gases and is often characterized by co-emission of oil or asphalt from the seeps [1]. Miniseepage is invisible seepage that occurs in an area where macroseeps are present. Though microseepage has the ability to occur globally in all places where underground deposits exist [2,3], macroseepage occurs in a much more limited number of discrete locations [3]. A recent database reports over 2100 global macroseeps in 89 countries [4]. However, even though macroseepage is more limited geographically than microseepage, individual macroseeps typically emit several orders of magnitude more methane and VOCs than microseeps $[4,5]$. Along with methane, the VOCs that are most commonly associated with geologic seepage are light alkanes, namely ethane, propane, $i$-butane, $n$-butane, $i$-pentane, and $n$-pentane. Although these gases react relatively slowly with hydroxyl radicals compared to other VOCs, they can nevertheless affect the hydroxyl radical reactivity, ultimately contributing to ozone formation in urban areas [6,7]. 


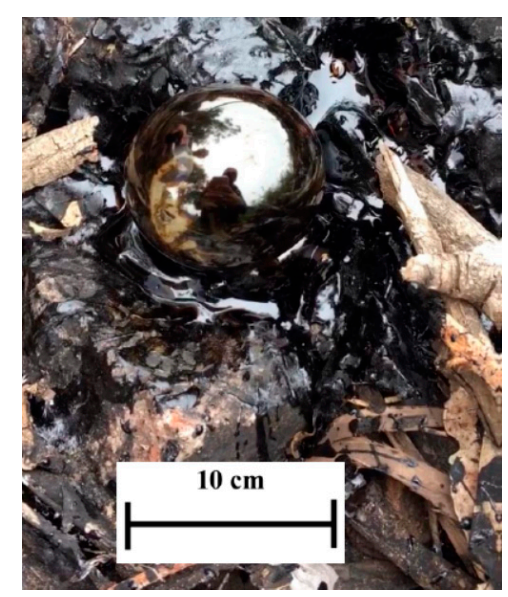

Figure 1. Example of macroseepage, as the asphalt bubble forming shows gas escape. Picture taken at the Carpinteria sample site.

A number of studies measuring terrestrial microseepage have been carried out in Europe, North America, and Asia. These studies have observed daily positive microseepage fluxes ranging from $\mu \mathrm{g} \mathrm{m}^{-2}$ to hundreds of $\mathrm{mg} \mathrm{m}^{-2}$ [8]. A smaller number of studies have measured emissions from terrestrial macroseepage; these studies have reported daily fluxes from individual seeps in the $\mathrm{kg} \mathrm{m}^{-2}$ range [9]. Recent studies have estimated that global macroseepage contributes 3-4 Tg of methane annually, compared to an annual global contribution of $25 \mathrm{Tg}$ of methane from microseepage [10]. Though previous studies have mainly focused on methane emissions, it has been estimated that annual global ethane and propane emissions from all types of geologic seepage are in the range of $2-4 \mathrm{Tg}$ and 1-2.4 Tg respectively [11].

Previous geologic seepage studies have been carried out by our research group at the La Brea Tar Pits in Los Angeles, California [12,13]. The second of these studies measured not only macroseepage but also associated miniseepage at La Brea. This study estimated that approximately $1000 \mathrm{~kg}$ of methane, more than $10 \mathrm{~kg}$ of ethane, and more than $4 \mathrm{~kg}$ of propane were emitted daily from the La Brea area. Another finding from these La Brea studies was that ratios of emitted gases not only varied at the surface, but also differed significantly from alkane ratios that are typically associated with oil and natural gas production and pipeline natural gas [14-16]. Furthermore, the gas wetness, or the relative amount of $\mathrm{C}_{2}-\mathrm{C}_{5}$ alkanes to methane, differed throughout the sampling locations. Most notably, the largest seep measured was significantly less methane-rich and gave a much lower $i$-butane to $n$-butane ratio than other seeps that were studied. The gas ratios at this largest seep were very similar to the ratios of gases in the underground reservoir, which had been measured in a previous study [17]. This suggested that the gas from this largest seep underwent less alteration between the reservoir and the surface, as the gases had a more direct, and thus faster, pathway to the surface. This alteration or 'processing' of the gas as it makes its way up through the soil was suggested as a contributing factor for the anomalous ratios of gases emitted at the surface seeps.

These findings at La Brea were not necessarily novel as similar uncommon ratios had been previously observed in other seepage studies. Unusually high $\mathrm{i} / n$-butane ratios of approximately 5 were found in a marine seep off the coast of Alaska [18]. These findings fit with other studies that suggest that $n$-alkanes are preferentially degraded by microbes compared to $i$-alkanes $[19,20]$. Additionally, studies of leakage gas from underground storage tanks have noted chemical fractionation during migration that can preferentially remove heavier $\left(\mathrm{C}_{2}+\right)$ alkanes compared to methane [21].

The current study seeks to further expand the database of macroseepage emissions of methane and $\mathrm{C}_{2}-\mathrm{C}_{5}$ alkanes. Three macroseepage sites in Southern California were sampled and the observed seepage rates and seepage ratios were compared to the previous results at $\mathrm{La}$ Brea. 


\section{Experiments}

\subsection{Description of Sampling Sites}

All three sampling sites were located within $200 \mathrm{~km}$ of Los Angeles, Figure 2. Despite their geographic proximity, each site was unique in terms of its geological features and climate. Additionally, individual seeps at each sampling location had differing physical characteristics.

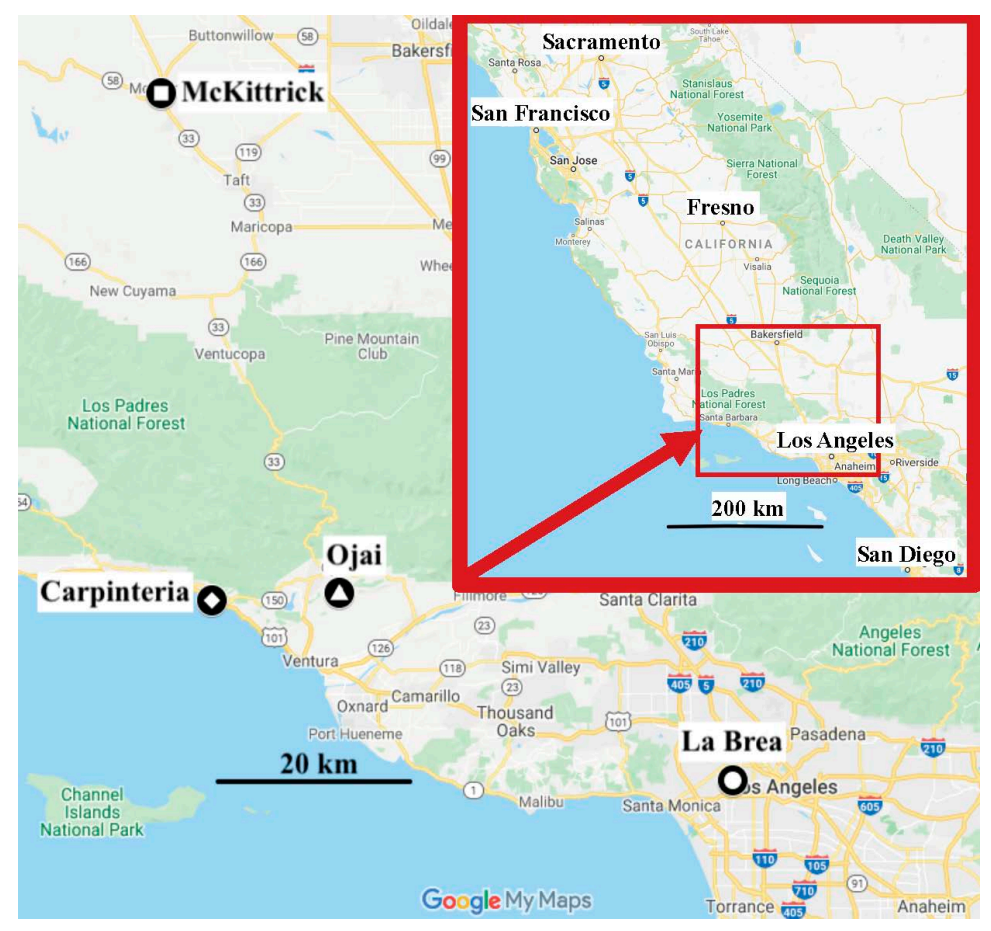

Figure 2. Map showing location of the three sampling sites plus La Brea.

Carpinteria is located approximately $20 \mathrm{~km}$ east of Santa Barbara, and approximately $130 \mathrm{~km}$ west-northwest of downtown Los Angeles. The seepage sampling location is located almost equidistant (3-4 km) from four mapped oil fields, the Summerland and Carpinteria Offshore Fields and the Rincon and Rincon Creek Onshore Fields. Though the sampling area was first mined in the 1850s and subsequently drilled starting in the 1920s, no active extraction currently takes place at the site. Previous wells were drilled to depths between 100 and $300 \mathrm{~m}$ [22]. However, the nearby Carpinteria Offshore Field, operational since the 1960s, is currently being drilled [23]. A number of natural offshore seeps also occur in this area and have been studied previously [24]. The Carpinteria climate is typical of coastal California, and the area is relatively dry, receiving approximately $48 \mathrm{~cm}$ of rainfall annually. During the sampling dates in June, weather conditions were typical for the season, with daily temperature maximums of approximately $20^{\circ} \mathrm{C}$ and cloudy skies. Samples were collected from a series of seeps located in Tar Pits Park $\left(34^{\circ} 23^{\prime} 15.7^{\prime \prime} \mathrm{N}, 119^{\circ} 30^{\prime} 46.4^{\prime \prime} \mathrm{W}\right)$ as well as seeps directly located

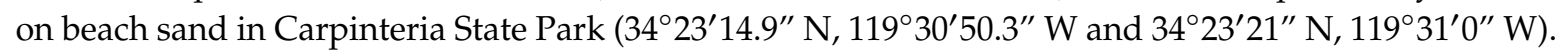

McKittrick is located approximately $50 \mathrm{~km}$ west of Bakersfield and approximately $200 \mathrm{~km}$ north-northwest of Los Angeles. The seeps are located above the McKittrick Oil Field [25]. The oil deposits are capped by a layer of Monterey shale that is up to $600 \mathrm{~m}$ in depth [26]. The field has been extensively drilled since the late 1800s and remains active [23]. Current active oil and gas wells that are closest to the seeps studied are drilled to depths of at least $300 \mathrm{~m}$ [27]. Additionally, the tar pits of the area are well known, as they are the second most extensive tar pits in California (after La Brea) and have been studied for their fossil record [28]. The sampling location is surrounded by scrubland and characterized by its dryness (approximately $17 \mathrm{~cm}$ of rainfall annually) and hot summers 
(average maximum July temperature of $37^{\circ} \mathrm{C}$ ). Samples were collected from McKittrick in late May on a sunny dry day with temperatures of approximately $25^{\circ} \mathrm{C}$. Samples were collected from mainly two areas. The first was a mostly dry creek bed adjacent to Highway 58 (centered around $35^{\circ} 17^{\prime} 40^{\prime \prime} \mathrm{N}$, $119^{\circ} 37^{\prime} 46^{\prime \prime} \mathrm{W}$ ), while the second was a mostly dry creek bed next to a service road just south of Highway 58 (centered around $35^{\circ} 17^{\prime} 34.7^{\prime \prime} \mathrm{N}, 119^{\circ} 37^{\prime} 51.8^{\prime \prime} \mathrm{W}$ ).

Ojai is located approximately $100 \mathrm{~km}$ northwest of Los Angeles. Samples were collected above the Sisar Creek area and Tip Top area in the Ojai Valley Oil Field [29]. These fields are part of the broader Ventura Petroleum Basin [30]. Both the Sisar Creek area and Tip Top area have been drilled for oil and gas production in the past, with the Sisar Creek $(\sim 225 \mathrm{~m})$ deposits being deeper than those at Tip Top, which naturally rose to the surface. Known faults in the Ojai Valley give the asphalt a migration pathway to the surface. Oil extraction has occurred in the area since the 1800s, and although the Sisar Creek area is still active, the Tip Top area has not had active extraction since the early 1900s [27,31]. Geologic seepage in Ojai was the subject of a previous study that looked at emissions of methane, carbon dioxide, and $\mathrm{C}_{2}-\mathrm{C}_{4} n$-alkanes from two seepage sites in the area [32]. In terms of climate, Ojai is similar to Carpinteria in annual rainfall $(48 \mathrm{~cm})$, but typically has warmer summers, with average high temperatures of approximately $30^{\circ} \mathrm{C}$. On the day of sample collection in mid-June, it was an unseasonably hot day with sunshine and a high temperature of $38^{\circ} \mathrm{C}$. Samples in Ojai were collected from two general areas. Some samples were collected in the Sisar Creek area on the eastern side of the Ojai Oil Field directly on the side of Highway 150 (centered around $34^{\circ} 26^{\prime} 01.0^{\prime \prime} \mathrm{N}, 119^{\circ} 07^{\prime} 30.1^{\prime \prime} \mathrm{W}$ ). Other samples were collected in the Tip Top area beside a trail that was the old Sulphur Mountain Road south of the town of Ojai (centered around $34^{\circ} 22^{\prime} 48.4^{\prime \prime}$ N, $119^{\circ} 17^{\prime} 54.7^{\prime \prime} \mathrm{W}$ ). Both Ojai sample sites had much larger nearby seeps in the vicinity that were visible, but not sampled due to a lack of access.

\subsection{Sample Collection and Analysis}

Samples were obtained by placing a $0.5 \mathrm{~m}$ by $0.5 \mathrm{~m}$ by $0.5 \mathrm{~m}$ aluminum chamber above active seeps, which were identified by visual bubbling or movement of wet asphalt. The chamber was not fitted onto already placed collars in the soil, as is the case with true quantitative flux chambers. However, the chamber was sealed on its outer edges with loose debris and dirt to attempt to trap all seeping gases. A pre-evacuated $2 \mathrm{~L}$ stainless-steel sampling canister was attached to the chamber via an ultratorr connection to a $1 / 4^{\prime \prime}$ (outer diameter) aluminum tube. In order to determine flux measurements from seeps, a reference canister was collected immediately after the deployment of the aluminum chamber. Then, the reference canister was removed and a second canister (termed "sample") was connected to the chamber. The sample canister was then collected after $10 \mathrm{~min}$. Flux measurements were determined via the difference between the sample and reference canisters. Subtraction of the reference canister from the sample canister also had the effect of background-correcting the data. Twenty-two samples were collected in this manner.

Unfortunately, the lack of a permanent collar made it impossible to ensure an airtight seal. Therefore, data collected with this sampling technique should be considered to be biased low, in that if a tight seal with the ground was not present, it is likely that some seeped gases escaped from the chamber leading to an underestimate of total flux. However, it is important to emphasize that this escape of gases does not affect the ratios of gases that were measured. Additional information on the chamber and canister system, including a picture of the setup and discussion about possible error introduced, is included in [13].

After collection, sampling canisters were analyzed on two analytical systems within the Loyola Marymount University laboratory. For $\mathrm{C}_{2}-\mathrm{C}_{5}$ hydrocarbons, $1105 \mathrm{~cm}^{3}$, at standard temperature and pressure were pumped from each canister and cryogenically pre-concentrated and then injected onto a PLOT column (Agilent J\&W Scientific, Santa Clara, CA, USA) within a Varian 3400 gas chromatography oven equipped with a flame ionization detector. The data were then analyzed on a PC utilizing Star Chromatography software. The reproducibility of this non-methane hydrocarbon (NMHC) analytical system was determined by measuring the relative standard deviation (RSD) of each compound; this was 
found to be less than $6 \%$ for all compounds measured in this study. The GC-FID was calibrated using air standards obtained from the Blake laboratory, prepared in lab at University of California, Irvine. Methane was analyzed on a separate system consisting of a $1 \mathrm{~m}$ packed column with $1 / 8^{\prime \prime}$ tubing filled with Carbosphere 80/100 (Grace Davison, Deerfield, MA, USA). This column was located inside of a Bruker 430 GC-FID. These methane measurements had an RSD of less than 5\%. Additional information on the analytical system can be found in [33].

Following quantification of chromatograms, fluxes for each sample site were determined. In order to report results for this study in a similar fashion as previous studies, magnitudes of fluxes are reported by mass, whereas all ratios that are presented are calculated by volume.

\section{Results and Discussion}

\subsection{Overview}

Of the twenty-one samples collected, not all the samples exhibited positive fluxes. Samples that exhibited negative or negligible fluxes were excluded from further analysis. Of the six samples collected at McKittrick, four showed positive fluxes, of the nine samples collected at Carpinteria, five presented positive fluxes, and all six samples at Ojai were positive. The negative or negligible fluxes were likely due to one of two causes. First, as previously mentioned, flux chambers without fixed in-ground collars were deployed. In some sample locations, it was difficult to achieve an adequate seal with the ground. This was especially problematic at the Carpinteria site, as there were many large branches at the asphalt seeps. If a sizeable seep of gas were made into the chamber prior to the reference sample being collected, large gaps between the ground and the chamber bottom would have allowed these gases to escape throughout the ten-minute sampling interval and led to vastly underreported, or even negative, fluxes. A second possibility for the negative and negligible fluxes would be the temporal nature of the seeps. The episodic nature of seepage has been previously observed [34]. It is possible that during the ten-minute flux chamber deployment the seep was not active.

Magnitudes of fluxes varied significantly within and between sites for both methane and VOCs and are presented in Table 1. Again, each sample in Table 1 was a result of a flux measurement from two individual sample canisters. Table 2 shows reference and sample canister concentrations for sample number 20 which was collected in Carpinteria. The high levels of methane and other gases in the reference canister in Table 2 are primarily caused by seepage occurring after placement of the chamber but prior to collection of the reference canister. It is worth pointing out that even small mass fluxes that are reflected in Table 1 are generally associated with large concentration differences (greatly above measurement uncertainty and detection limits) between the reference and sample canisters. In general, the magnitude changes shown in Table 1 were consistent with visual observations, as the Carpinteria sampling sites exhibited the most vigorous surface bubbling. The largest fluxes were observed at Carpinteria, with maximum methane and ethane fluxes of $840 \mathrm{mg} \mathrm{h}^{-1}$ and $6.4 \mathrm{mg} \mathrm{h}^{-1}$, respectively. Maximum fluxes at the other sites were between two and three orders of magnitude smaller, with maximum fluxes of methane and ethane of $8.2 \mathrm{mg} \mathrm{h}^{-1}$ and $20 \mu \mathrm{g} \mathrm{h}^{-1}$ at McKittrick and $3.8 \mathrm{mg} \mathrm{h}^{-1}$ and $1.9 \mu \mathrm{g} \mathrm{h}^{-1}$ at Ojai. The maximum fluxes found in this study are generally small compared to previous studies at La Brea, where fluxes reached up to $17 \mathrm{~g} \mathrm{~h}^{-1}$ for methane and $270 \mathrm{mg} \mathrm{h}^{-1}$ of ethane [12]. However, it is difficult to infer conclusions regarding flux strength or overall emissions from each site given the small numbers of samples collected in the current study and potential errors introduced by unsealed chamber leakage. 
Table 1. Flux magnitudes by mass $(\mu \mathrm{g} / \mathrm{h})$ for each of the fifteen positive-flux seeps that were sampled in this study.

\begin{tabular}{ccccccccc}
\hline Location & Sample & Methane & Ethane & Propane & $\boldsymbol{i}$-Butane & $\boldsymbol{n}$-Butane & $\boldsymbol{i}$-Pentane & $\boldsymbol{n}$-Pentane \\
\hline McKittrick & 1 & 590 & 0.27 & 0.37 & 0.052 & 0.095 & 0.13 & 0.19 \\
McKittrick & 3 & 10.6 & 1.8 & 2.9 & 0.61 & 0.66 & 0.88 & 1.3 \\
McKittrick & 4 & 360 & 0.92 & 3.7 & 0.88 & 0.71 & 0.88 & 1.1 \\
McKittrick & 5 & 8200 & 20 & 1.9 & 0.31 & 0.18 & 0.17 & 0.28 \\
Carpinteria & 11 & 840,000 & 6400 & 104 & 21 & 1.08 & 0.33 & 0.35 \\
Carpinteria & 20 & 3300 & 2.2 & 6.9 & 15 & 1.1 & 37 & 0.75 \\
Carpinteria & 21 & 23,000 & 3.1 & 7.0 & 16 & 0.53 & 24 & 0.39 \\
Carpinteria & 22 & 7500 & 2.4 & 6.5 & 14 & 0.69 & 27 & 0.44 \\
Carpinteria & 23 & 11,000 & 3.1 & 9.4 & 23 & 1.11 & 44 & 0.67 \\
Ojai & 13 & 3300 & 1.12 & 1.5 & 0.42 & 1.00 & 0.68 & 1.07 \\
Ojai & 14 & 160 & 1.4 & 1.8 & 0.46 & 1.3 & 0.43 & 2.9 \\
Ojai & 15 & 290 & 0.35 & 0.67 & 0.103 & 0.35 & 0.13 & 0.099 \\
Ojai & 17 & 3800 & 1.5 & 0.50 & 0.0052 & 0.57 & 0.15 & 0.30 \\
Ojai & 18 & 910 & 1.9 & 2.2 & 0.59 & 0.95 & 0.57 & 0.94 \\
Ojai & 19 & 110 & 0.86 & 0.99 & 0.027 & 1.2 & 0.15 & 0.31 \\
\hline
\end{tabular}

Table 2. Concentrations (in ppbv, except methane) for reference and sample canisters that were used to calculate sample number 20 .

\begin{tabular}{lccccccc}
\hline Canister & Methane (ppmv) & Ethane & Propane & $\boldsymbol{i}$-Butane & $\boldsymbol{n}$-Butane & $\boldsymbol{i}$-Pentane & $\boldsymbol{n}$-Pentane \\
\hline 20-reference & 3.20 & 1.6 & 1.1 & 0.75 & 0.31 & 1.2 & 0.06 \\
20-sample & 9.82 & 4.1 & 6.3 & 9.4 & 0.94 & 18 & 0.40 \\
\hline
\end{tabular}

\subsection{Gas Ratios}

Various ratios were determined for the three reported sites and compared to previously reported seepage studies and are shown in Table 3. The relative amount of methane in each sample was investigated using $\mathrm{C} 1 /(\mathrm{C} 2+\mathrm{C} 3)$, which is known as the Bernard ratio. This ratio is closely related to the inverse of the true gas wetness, which would also include butane and pentane. However, in this case the Bernard ratio was used to facilitate comparison with previous studies that did not measure $\mathrm{C}_{4}+$ gases. The $\mathrm{C} 1 /(\mathrm{C} 2+\mathrm{C} 3)$ ratio varied by location as well as within locations. Figure 3 shows how this ratio changed for individual sampling locations versus the mass of seeped methane. In general, there did not appear to be a strong correlation between the strength of the seep and the $\mathrm{C}_{1} /\left(\mathrm{C}_{2}+\mathrm{C}_{3}\right)$ ratio for the three locations in this study. However, it must be noted that the lack of a strong relationship could be due to bias introduced in the sampling method. Though the limited number of samples showed that McKittrick was the wettest gas followed by Ojai and Carpinteria, each location had at least one individual sample that was within the range of the other two locations. Variability of the Bernard ratio could be due to several factors. First, this ratio can vary based on the composition of the oil or gas deposit [35]. Secondly, this ratio has been observed to increase during migration from underground deposit to surface [9]. Therefore, if all deposits contained the same wetness of oil/gas, it could be expected that deeper deposits would emit more methane-rich gas at the surface, as a greater percentage of the ethane and propane would be lost during migration. However, in this study, the deposit composition is not well known at all three sites, making further analysis on the causes of differing surface $\mathrm{C} 1 /(\mathrm{C} 2+\mathrm{C} 3)$ ratios difficult. 
Table 3. Gas ratios by volume (v/v) observed by site in this and previous studies [30].

\begin{tabular}{cccc}
\hline Location & $\mathrm{C}_{\mathbf{1}} /\left(\mathrm{C}_{\mathbf{2}}+\mathrm{C}_{\mathbf{3}}\right)$ & $\boldsymbol{i}-\mathrm{C}_{\mathbf{4}} / \boldsymbol{n}-\mathrm{C}_{\mathbf{4}}$ & $\boldsymbol{i}-\mathrm{C}_{\mathbf{5}} / \boldsymbol{n}-\mathrm{C}_{\mathbf{5}}$ \\
\hline McKittrick-this study & 760 & 1.1 & 0.68 \\
Carpinteria-this study & 2200 & 21 & 48 \\
Ojai-this study & 1400 & 0.27 & 0.61 \\
La Brea & 90 & 11 & 49 \\
Ojai Seeps [30] & 220 & - & - \\
Ojai Reservoir [30] & 10 & - & - \\
Carpinteria Exposed Pipe & 2200 & 1.6 & 9.4 \\
\hline
\end{tabular}

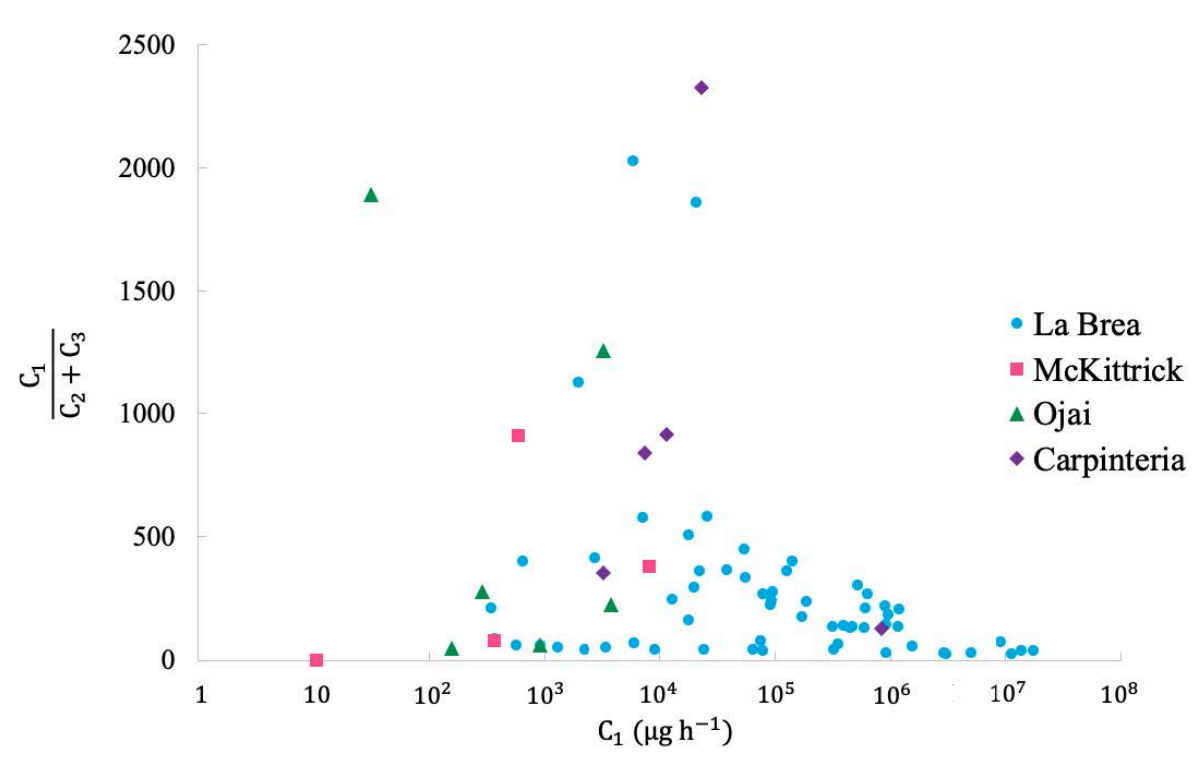

Figure 3. Plot of methane flux vs. $\mathrm{C} 1 /(\mathrm{C} 2+\mathrm{C} 3)$ ratio at the three sites and La Brea.

A second gas ratio investigated was the relative amount of $i$-alkanes to $n$-alkanes. Classically, it is observed that there is a higher ratio of $n$-butane and $n$-pentane in emissions from hydrocarbon deposits in comparison to their iso counterparts. Specifically, ambient ratios of $i$-butane to $n$-butane in the U.S. are approximately 0.5 , while ratios from natural gas fields are typically even lower [36,37]. $i$-Pentane to $n$-pentane ratios of approximately 2 are typical for ambient U.S. samples while ratios from raw natural gas and oil and natural gas impacted areas have been reported as 0.86 and less than 1 respectively $[6,15,36,38-41]$. However, studies have suggested that during gas migration to the surface, the iso gases become more enhanced. One explanation for this has been that microbes preferentially degrade $n$-alkanes $[19,20]$. The current study showed wide variability of $i$-butane $/ n$-butane and $i$-pentane/n-pentane ratios at the three sites, as shown in Figure 4 . Similar to the $C_{1} /\left(C_{2}+C_{3}\right)$ ratio, the $i / n$ ratios did not seem to be strongly influenced by the strength of the individual seep. Again, it should be noted that the lack of a strong relationship could be affected by sample collection bias. Ojai samples exhibited an $i / n$ ratio for both $C_{4}$ and $C_{5}$ of less than one; this sort of ratio is typical of what has been reported from oil and gas extraction emissions previously. McKittrick showed slightly higher ratios, but still near 1 for $i / n$-butane and under 1 for $i / n$-pentane. Carpinteria samples showed significantly different ratios, with an $i / n$-butane ratio of 21 and an $i / n$-pentane ratio of 48 . These Carpinteria ratios are even more enhanced than the large $i / n$ ratios seen during the La Brea studies. These greatly enhanced $i / n$ ratios at Carpinteria suggest that microbial degradation is occurring between subsurface reservoir and surface emissions that is not occurring to the same degree at McKittrick or Ojai. This suggestion is further supported by the greater amounts of $i$-butane and $i$-pentane relative to ethane and propane in Carpinteria sample numbers 20 thru 23. Normally, it would be expected that $C_{2}$ and $C_{3}$ gases would exceed levels of $C_{4}$ and $C_{5}$ from hydrocarbon deposits. The fact that this is not observed in these samples hints that all $n$-alkanes are being consumed as the gases migrate from 
underground deposit to surface. Carpinteria samples also exhibited interesting intra-site variability of these $i / n$ ratios, which is further discussed in following sections.
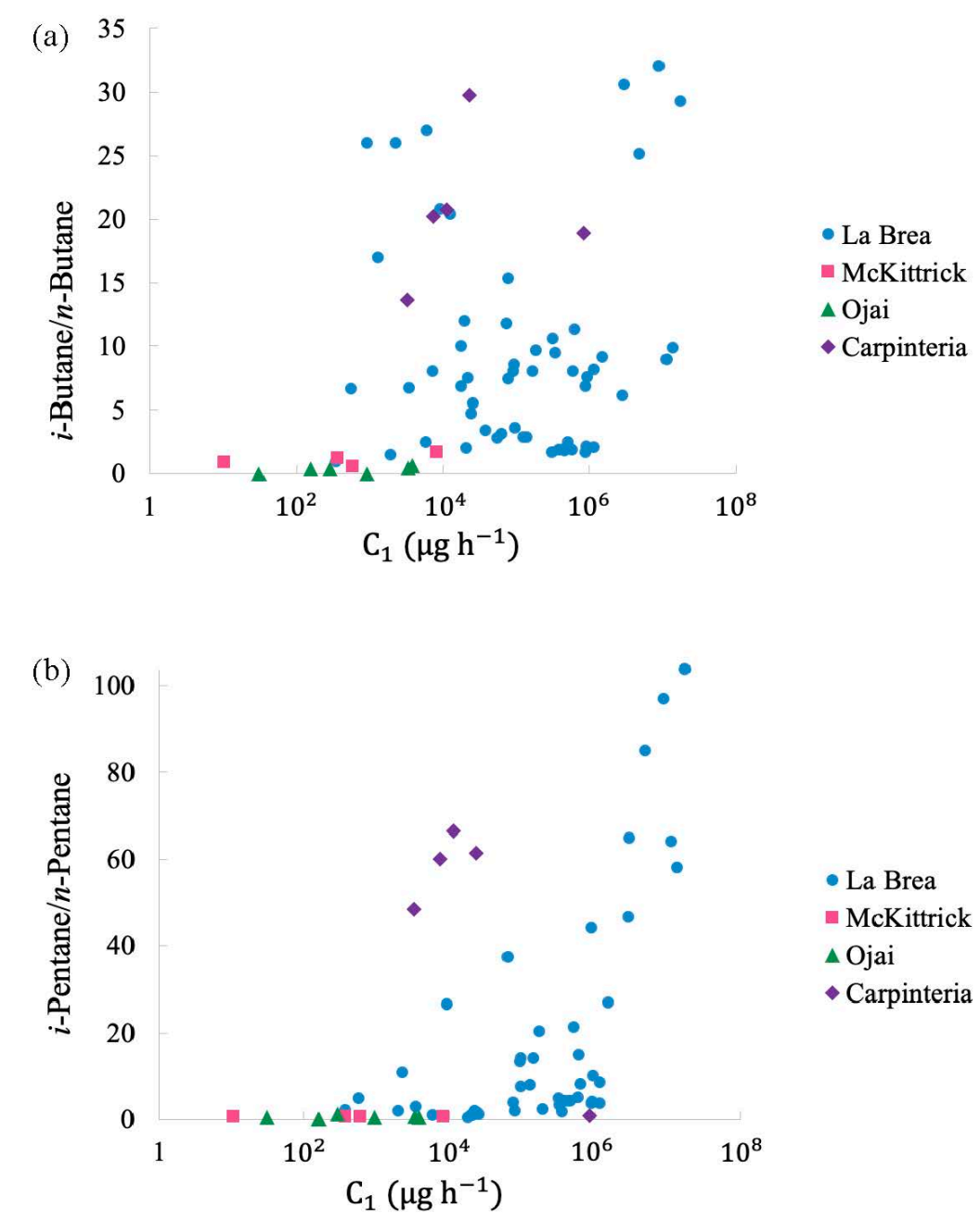

Figure 4. Plots of methane flux vs. (a) $i$-butane $/ n$-butane ratio and (b) $i$-pentane $/ n$-pentane ratio at the three sites and La Brea.

\subsection{Ojai Comparison}

As previously mentioned, the Ojai site had been previously studied by Duffy et al. between 2003 and 2005 [32]. This previous study made measurements in the North Sulfur Mountain and Silverthread oil fields; these fields are approximately $15 \mathrm{~km}$ northeast of the Tip Top oil field where four samples were collected in the current study. However, the two samples collected in this study as part of the Sisar Creek Oil Field were collected only a distance of $1.3 \mathrm{~km}$ from the North Sulfur Mountain samples collected in the earlier study. The previous study had access to some of the largest seeps in the area, and the observed methane seepage rates of up to $300 \mathrm{~g} \mathrm{~h}^{-1}$ were approximately five orders of magnitude greater than the maximum Ojai flux rates observed in this study. In terms of gas composition, the earlier study found relatively greater ethane and propane amounts (average $\mathrm{C} 1 /(\mathrm{C} 2+\mathrm{C} 3)$ ratio of 220) compared with this study's observations (average $\mathrm{C} 1 /(\mathrm{C} 2+\mathrm{C} 3)$ ratio of 1360$)$. Perhaps most interestingly, the earlier study was able to measure the composition of the reservoir gas for both the North Sulfur Mountain and Silverthread fields. The reservoir gas samples were much less methane rich, exhibiting a C1/(C2 + C3) for North Sulfur Mountain and Silverthread of 10.9 and 8.1 respectively. This indicates that the gas is changing character as it migrates from deposit to the 
surface, becoming more methane rich. This is likely due to a combination of microbial degradation and the preferential loss of ethane and propane because of their adsorption and solubility properties that has been previously observed at seepage sites $[9,21]$. This may also explain the more methane-rich flux gases that were observed in this study; it makes sense that in larger seeps (where gas makes it to the surface in a shorter amount of time), the gas would undergo less change/processing and would maintain a composition that was closer to the original composition of the deposit. It should also be noted that differences in sample collection protocol could also contribute to observed differences between the current study and work carried out by Duffy et al.

\subsection{Anthropogenic Versus Natural Seepage}

The Carpinteria site allowed for an interesting look at how anthropogenically influenced emissions vary from natural seepage. At Carpinteria, one sample was collected from the top of an exposed pipe that contained bubbling asphalt, Figure 5. It is believed that this represents remains of an old oil well [20]. This pipe gives gases a preferred route to the surface, which theoretically means they spend less time making the journey from underground reservoir to surface. The isomer gas ratios observed coming from the pipe varied significantly from the other Carpinteria samples. Both the $i-C_{4} / n-C_{4}$ ratio and the $i-C_{5} / n-C_{5}$ ratio were greatly depressed compared to the ratios at the other seepage sites, as shown in Figure 6. This would suggest that the processing that gas undergoes on its way from deposit to surface is at least in part responsible for the elevated $i / n$ ratios observed, since the gases emitted via the pipe would have not only a shorter processing time but less interaction with soil and water. Somewhat surprisingly, the $\mathrm{C} 1 /(\mathrm{C} 2+\mathrm{C} 3)$ ratio did not vary significantly for gases coming from this exposed pipe. The $i / n$ ratios observed are similar to earlier findings at La Brea, where gas emissions at very high emission sites (indicating ease in passage) varied greatly and seemed to exhibit less indications of gas processing than other seeps.

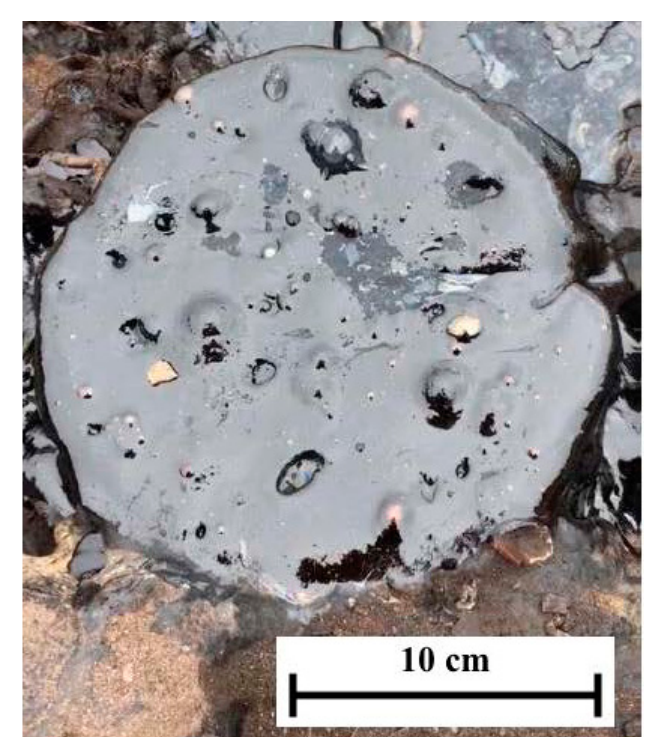

Figure 5. Exposed pipe with bubbling asphalt that was sampled at Carpinteria. 


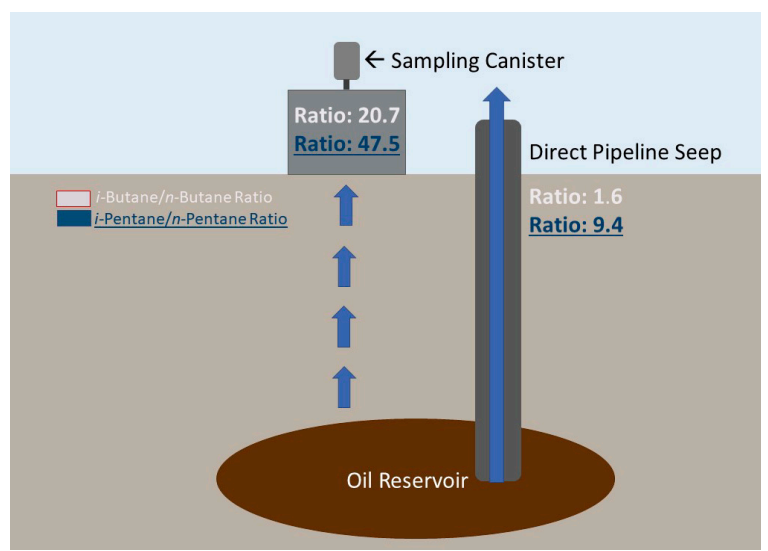

Figure 6. Cartoon showing anthropogenic influence on $i / n$ gas ratios at Carpinteria.

\subsection{Implications and Future Directions}

As seen within the study of McKittrick, Ojai, and Carpinteria macroseepage sites, there are significantly different gas ratio signatures depending upon the location of the seep. In addition to significant intra-site variability, there were also significantly different ratios within samples at the same site. The two largest Ojai fluxes, samples 13 and 17, exhibited $C 1 /(C 2+C 3)$ ratios approximately ten times higher (3400 versus 350) than the other four Ojai sites. Most interesting were the differences between Carpinteria sample sites. One sampling site was located approximately $300 \mathrm{~m}$ west of the other sites. Fluxes measured from this site were unique in two ways. First, the single site exhibited much greater amounts of the $\mathrm{C}_{2}+$ alkanes, as its $\mathrm{C} 1 /(\mathrm{C} 2+\mathrm{C} 3)$ ratio of 240 was more than ten times less than the average of the other four samples collected at Carpinteria. Second, the site was unique in that even though it was generally rich in $\mathrm{C}_{2}+$ alkanes, it did not exhibit any appreciable amount of $i$-pentane, which resulted in a much lower $i$-pentane to $n$-pentane ratio (0.9) than the other four samples (average of 60). Future studies that employ more samples will be useful in determining if, how, and why ratios of emitted gases vary over relatively small distances or short time intervals.

Contributing factors for both these differing intra-site and inter-site ratios may include gas composition of the deposit, deposit depth, strength of seep, and degree of microbial degradation. Because of these variables, it can be stated that there is no one singular characteristic of geological seepage in terms of its gas ratios. This is also true of other emission sources, such as the percentage of ethane in U.S. pipeline natural gas, which may vary from $1.6 \%$ to $2.7 \%$ ethane in various cities $[16,42]$ or the methane to ethane ratio from oil and natural gas fields which can change from approximately 11:1 to 1:1 [43]. Headspace vapor from gasoline samples can also vary up to an order of magnitude by season for butane components [44]. However, the variability of VOC ratios in these emission sources is smaller than the almost two orders of magnitude difference between $i / n$ pentane ratios observed in this study. Thus, there is no one characteristic "fingerprint" that can be applied to macroseepage. This means that future estimates on the role that geologic seepage plays in VOC budgets in a given city or region should be based upon emission data from seeps in that same area. For global or national budgets, a range of macroseepage studies should be used. Moving forward, additional studies carried out at new sites are important to measure ratios of emitted gases and in order to better understand the role that geologic seepage plays in both local and global budgets of methane and VOCs.

Future studies at these and other sites in Southern California will build upon this preliminary study. These future studies will incorporate not only additional samples but will measure a wider suite of gases. Both isotopic measurements of $C$ in methane and measurements of non-hydrocarbon gases $\left(\mathrm{N}_{2}\right.$, $\mathrm{O}_{2}, \mathrm{CO}_{2}$ ) can be used to obtain more information about gas sources and can specifically be used to better differentiate reservoir gas signals from possible contributions from biogenic methane [1]. The relative amount of $C_{5}-C_{9}$ gases can also potentially be used to better gauge the degree of degradation from the source that has occurred [45]. 


\section{Conclusions}

Flux measurements of methane and light alkanes showed wide variability in terms of magnitude and gas ratios from Carpinteria, McKittrick, and Ojai seepage sites in Southern California. These three sites also showed significant differences from previous seepage studies carried out at the La Brea Tar Pits in Los Angeles. Carpinteria samples showed the most evidence of 'processing' between the deposit and the surface, exhibiting highly elevated ratios of more than 20:1 for $i$-butane $/ n$-butane and more than $45: 1$ for $i$-pentane/ $n$-pentane. Large differences were also observed between sample seeps that were anthropogenic versus natural, with the anthropogenically-influenced samples showing less processing or alteration from ratios that are typical of underground oil or gas deposits.

The large differences in emitted gases at each site have important implications when estimating the relative importance of macroseepage in the atmospheric budget of a given gas. Unlike VOC emission sources that are relatively constant, geologic seepage appears not to have a single source fingerprint. This means that studies that seek to incorporate macroseepage into local or regional atmospheric budgets should not use generalized composition measurements that were made in other locations. Though composition of deposit, deposit depth, geology of region, and microbial environment may all play roles in shaping the gas ratios emitted at the surface, further research is needed in order to assess the relative importance of these variables in the studied locations.

Author Contributions: All three authors contributed to sample collection, sample analysis, and data analysis. B.M.W. wrote the first version of the manuscript, G.D.B. worked on figures for the manuscript and L.A.D. worked on final manuscript revision. All authors have read and agreed to the published version of the manuscript.

Funding: This research received no external funding.

Acknowledgments: The authors would like to thank the LMU Department of Chemistry and Biochemistry and Seaver College of Science and Engineering for research support.

Conflicts of Interest: The authors declare no conflict of interest.

\section{References}

1. Abrams, M.A. Evaluation of Near-surface Gases in Marine Sediments to Assess Subsurface Petroleum Gas Generation and Entrapment. Geosciences 2017, 7, 35. [CrossRef]

2. Etiope, G.; Klusman, R.W. Geologic Emissions of Methane to the Atmosphere. Chemosphere 2002, 49, 777-789. [CrossRef]

3. Kvenvolden, K.A.; Rogers, B.W. Gaia's Breath-global methane exhalations. Mar. Pet. Geol. 2005, 22, 579-590. [CrossRef]

4. Etiope, G. Natural Gas Seepage: The Earth's Hydrocarbon Degassing, 1st ed.; Springer International Publishing: New York, NY, USA, 2015.

5. Abrams, M.A. Significance of hydrocarbon seepage relative to subsurface petroleum generation and entrapment. Mar. Pet. Geol. 2005, 22, 457-477. [CrossRef]

6. $\quad$ Benedict, K.B.; Zhou, Y.; Sive, B.C.; Prenni, A.J.; Gebhart, K.A.; Fischer, E.V.; Evanoski-Cole, A.; Sullivan, A.P.; Callahan, S.; Schichtel, B.A.; et al. Volatile organic compounds and ozone in Rocky Mountain National Park during FRAPPE. Atmos. Chem. Phys. 2019, 19, 499-521. [CrossRef]

7. McDuffie, E.E.; Edwards, P.M.; Gilman, J.B.; Lerner, B.M.; Dubé, W.P.; Trainer, M.; Wolfe, D.E.; Angevine, W.M.; De Gouw, J.; Williams, E.J.; et al. Influence of Oil and Gas Emissions on Summertime Ozone in the Colorado Northern Front Range. J. Geophys. Res. Atmos. 2016, 121, 8712-8729. [CrossRef]

8. Etiope, G. Natural Emissions of Methane from Geological Seepage in Europe. Atmos. Environ. 2009, 43, 1430-1443. [CrossRef]

9. Etiope, G.; Nakada, R.; Tanaka, K.; Yoshida, N. Gas Seepage from Tokamachi Mud Volcanoes, Onshore Niigata Basin (Japan): Origin, Post-genetic Alterations and $\mathrm{CH}_{4}-\mathrm{CO}_{2}$ Fluxes. Appl. Geochem. 2011, 26, 348-359. [CrossRef]

10. Etiope, G. Methane Uncovered. Nat. Geosci. 2012, 5, 373-374. [CrossRef]

11. Etiope, G.; Ciccioli, P. Earth's Degassing: A Missing Ethane and Propane Source. Science 2009, $323,478$. [CrossRef] 
12. Etiope, G.; Doezema, L.A.; Pacheco, C. Emission of Methane and Heavier Alkanes from the La Brea Tar Pits Seepage Area, Los Angeles. J. Geophys. Res. 2017, 122, 12008-12019. [CrossRef]

13. Weber, D.; Marquez, B.A.; Taylor, C.; Raya, P.; Contreras, P.; Howard, D.; Doezema, L.A. Macroseepage of Methane and Light Alkanes at the La Brea Tar Pits in Los Angeles. J. Atmos. Chem. 2017, 74, 339-356. [CrossRef]

14. Gilman, J.B.; Lerner, B.M.; Kuster, W.C.; de Gouw, J.A. Source Signatures of Volatile Organic Compounds from Oil and Natural Gas Operations in Northeastern Colorado. Environ. Sci. Technol. 2013, 47, 1297-1305. [CrossRef] [PubMed]

15. Swarthout, R.F.; Russo, R.S.; Zhou, Y.; Hart, A.H.; Sive, S.C. Volatile organic compound distributions during the NACHTT campaign at the Boulder Atmospheric Observatory: Influence of urban and natural gas sources. J. Geophys. Res. Atmos. 2013, 118, 10614-10637. [CrossRef]

16. Wennberg, P.O.; Mui, W.; Wunch, D.; Kort, E.A.; Blake, D.R.; Atlas, E.L.; Santoni, G.W.; Wofsy, S.C.; Diskin, G.S.; Jeong, S.; et al. On the Sources of Methane to the Los Angeles Atmosphere. Environ. Sci. Technol. 2012, 46, 9282-9289. [CrossRef]

17. Jeffrey, A.W.A.; Alimi, H.M.; Jenden, P.D. Geochemistry of Los Angeles Basin Oil and Gas Systems. In M 52: Active Margin Basins, 1st ed.; AAPG: Oklahoma, OK, USA, 1991; pp. 197-219.

18. Kvenvolden, K.A.; Weliky, K.; Nelson, H.; DesMarais, D.J. Submarine seep of carbon dioxide in Norton Sound Alaska. Science 1979, 205, 1264-1266. [CrossRef]

19. Igari, S.-I.; Maekawa, T.; Suzuki, Y. Pentane and hexane isomers in natural gases from oil and gas fields in Akita, Niigata and Hokkaido, Japan: Determination factor in their isomer ratios. Geochem. J. 2007, 41, 57-63. [CrossRef]

20. Das, N.; Chandran, P. Microbial degradation of petroleum hydrocarbon contaminants: An overview. Biotechnol. Res. Int. 2011, 2011, 941810. [CrossRef]

21. Coleman, D.D.; Meents, W.F.; Liu, C.L.; Keough, R.A. Isotopic Identification of Leakage Gas from Underground Storage Reservoirs: A Progress Report; Illinois State Geological Survey: Illinois Petroleum, IL, USA, 1977; Volume 111, pp. 1-10.

22. Wilkerson, G. Walking Tour Carpinteria Oil Seeps Santa Barbara, California. Available online: https: //www.academia.edu/37644752 (accessed on 3 November 2019).

23. Annual Reports of the State Supervisor of Oil and Gas. Report of California Oil and Gas Production Statistics, 2018; California Department of Conservation: Sacramento, CA, USA, 2018.

24. Leifer, I. A synthesis review of emissions and fates for the coal oil point marine hydrocarbon seep field and California marine seepage. Geofluids 2019, 2019, 1-48. [CrossRef]

25. Church, C.C. The McKittrick Tar Seeps. Geology and Oil Fields, West Side Southern San Joaquin Valley; American Association of Petroleum Geologists: Tulsa, OK, USA, 1968.

26. Taff, J.A. Geology of McKittrick Oil Field and Vicinity, Kern County, California. Bull. AAPG 1933, 17, 1-15.

27. California Departments of Conservation, Well Finder. Available online: https://www.conservation.ca.gov/ calgem/Pages/Wellfinder.aspx (accessed on 11 March 2020).

28. Fox-Dobbs, K.; Dundas, R.; Trayler, R.; Holroyd, P. Paleoecological Implications of New Magafaunal ${ }^{14} \mathrm{C}$ Ages from the McKittrick Tar Seeps, California. J. Vertebr. Paleontol. 2014, 34, 220-223. [CrossRef]

29. Huftile, G.J. Thin-skinned tectonics of the Upper Ojai Valley and Sulphur Mountain area, Ventura Basin, California. Am. Assoc. Pet. Geol. Bull. 1991, 75, 1353-1373.

30. Davis, T.L.; Namson, J.S.; Gordon, S.A. Ventura Basin Oil Fields: Structural Setting and Petroleum System. In Proceedings of the Joint Annual Meeting of PSAAPG \& Coast Geologic Society, Oxnard, CA, USA, 2-8 May 2015.

31. Wilkerson, G. Geology and Oil Development History of the Ventura Basin Field Guide: 2018 Edition. Available online: https://www.academia.edu/31781887 (accessed on 3 November 2019).

32. Duffy, M.; Kinnaman, F.S.; Valentine, D.L.; Keller, E.A.; Clark, J.F. Gaseous emission rates from natural petroleum seeps in the upper Ojai Valley, California. Environ. Geosci. 2007, 14, 197-207. [CrossRef]

33. Doezema, L.A.; Bigley, C.; Canzi, G.; Chang, K.; Hirning, A.J.; Lee, J.; Von der Ahe, N. The influence of sampling protocol on non-methane hydrocarbons in Los Angeles. Atmos. Environ. 2010, 44, 900-908. [CrossRef]

34. Roberts, H.; Carney, R.S. Evidence of episodic fluid, gas, and sediment venting on the northern Gulf of Mexico continental slope. Econ. Geol. 1997, 92, 863-879. [CrossRef] 
35. Zumberge, J.; Ferworn, K.; Brown, S. Isotopic reversal ('rollover') in shale gases produced from the Mississippian Barnett and Fayetteville formations. Mar. Pet. Geol. 2012, 31, 43-52. [CrossRef]

36. Rossabi, S.; Helmig, D. Changes in atmospheric butanes and pentanes and their isomeric ratios in the continental United States. J. Geophys. Res. Atmos. 2018, 123, 3772-3790. [CrossRef]

37. Zhongying, M.; Jianfa, C.; Jing, W.; Guannan, W.; Chen, Z.; Wei, L. Application of butane geochemistry of natural gas in hydrocarbon exploration. Pet. Sci. 2012, 9, 455-462.

38. Thompson, C.R.; Hueber, J.; Helmig, D. Influence of oil and gas emissions on ambient atmospheric non-methane hydrocarbons in residential areas of Northeastern Colorado. Elem.-Sci. Anthr. 2014, 3, 4707-4715. [CrossRef]

39. Swarthout, R.F.; Russo, R.S.; Zhou, Y.; Miller, B.M.; Mitchell, B.L.; Horsman, E.; Lipsky, E.M.; McCabe, D.C.; Baum, E.; Sive, B.C. Impact of Marcellus Shale natural gas development in Southwestern Pennsylvania on volatile organic compound emissions and regional air quality. Environ. Sci. Tech. 2015, 49, 3175-3184. [CrossRef]

40. Prenni, A.J.; Day, D.E.; Evanoski-Cole, A.R.; Sive, B.C.; Hecobian, A.; Zhou, Y.; Gebhart, K.A.; Hand, J.L.; Sullivan, A.P.; Li, Y.; et al. Oil and gas impacts on air quality in federal lands in the Bakken region: An overview of the Bakken Air Quality Study and first results. Atmos. Chem. Phys. 2016, 16, 1401-1416. [CrossRef]

41. Benedict, K.B.; Prenni, A.J.; El-Sayed, M.M.H.; Hecobian, A.; Zhou, Y.; Gebhart, K.A.; Sive, B.C.; Schichtel, B.A.; Collett, J.L. Volatile organic compounds and ozone at four national parks in the southwestern United States. Atmos. Environ. 2020, 239, 117783. [CrossRef]

42. McKain, K.; Down, A.; Raciti, S.M.; Budney, J.; Hutyra, L.R.; Floerchinger, C.; Herndon, S.C.; Nehrkorn, T.; Zahniser, M.S.; Jackson, R.B.; et al. Methane emissions from natural gas infrastructure and use in the urban region of Boston, Massachusetts. Proc. Natl. Acad. Sci. USA 2015, 112, 1941-1946. [CrossRef] [PubMed]

43. Peischl, J.; Eilerman, S.J.; Neuman, J.A.; Aikin, K.C.; de Gouw, J.; Gilman, J.B.; Herndon, S.C.; Nadkarni, R.; Trainer, M.; Warneke, C.; et al. Quantifying methane and ethane emissions to the atmosphere from central and western U.S. oil and natural gas production regions. J. Geophys. Res. Atmos. 2018, 123, 7725-7740. [CrossRef]

44. Genter, D.R.; Harley, R.A.; Miller, A.M.; Goldstein, A.H. Diurnal and seasonal variability of gasoline-related volatile organic compound emissions in Riverside, California. Environ. Sci. Tech. 2009, 43, 4247-4252. [CrossRef] [PubMed]

45. George, S.C.; Boreham, C.J.; Minifie, S.A.; Teerman, S.C. The effect of minor to moderate biodegradation on $C_{5}$ to $C_{9}$ hydrocarbons in crude oils. Org. Geochem. 2002, 33, 1293-1317. [CrossRef] 